\title{
Effects of different levels of expanded perlite on the performance and egg quality traits of laying hens
}

\author{
Fatma Karakas Oguz ${ }^{1 *}$, Hidir Gumus ${ }^{1}$, Mustafa Numan Oguz ${ }^{1}$, Kadir Emre Bugdayci ${ }^{1}$, Hüseyin \\ Dagli ${ }^{1}$, Yasin Ozturk ${ }^{2}$
}

\footnotetext{
${ }^{1}$ Mehmet Akif Ersoy University, Veterinary Faculty, Animal Nutrition and Nutritional Diseases Department, Burdur, Turkey

${ }^{2}$ Bingol University, Veterinary Faculty, Farmacology and Toxicology Department, Bingol, Turkey.
}

\begin{abstract}
The influence of different levels of expanded perlite on the performance and egg quality traits was studied in laying hens. Forty Lohmann Brown females at 30 weeks of age were randomly assigned to four groups consisting of five replicates with two hens in each. Four diet groups were supplemented with $0 \%$ (control group), $1 \%, 2 \%$, and $3 \%$ perlite, respectively. Feed and water were provided ad libitum. There were no significant differences in final body weight, feed intake, egg yield, and egg weight. Feed conversion ratio and egg weight decreased with addition of $2 \%$ perlite. Dietary perlite supplementation has no significant effects on shape, yolk, and albumen index. Haugh unit was affected significantly by addition of $2 \%$ perlite. Fecal $\mathrm{pH}$, dry matter, and $\mathrm{NH}_{3}-\mathrm{N}$ did not significantly differ among treatments. Dietary perlite has no negative effect on performance and egg quality traits except $2 \%$ perlite group. Dietary expanded perlite can be added at $1 \%$ level in laying hen rations without changing the animal performance.
\end{abstract}

Key Words: egg, performance, perlite, poultry

\section{Introduction}

Perlite is a glassy volcanic rock (Tekin, 2004). The name of "perlit" is derived from the word "perle", which means pearl (Orhun, 1969). Raw perlite is transparent and greyish or gloss black rock of hydrated aluminosilicates of alkali (i.e., $\mathrm{Na}+, \mathrm{K}+$ ) and alkaline earth cations (Ghalehkandi et al., 2014). Perlite expands by 10-30 times its original volume when heated up to $700-1200{ }^{\circ} \mathrm{C}$. This expansion is due to the presence of two to six percent combined water in the crude perlite rock. Expanded perlite is an excellent thermal and acoustical insulator; it resists fire, and is an ultra-lightweight material (Talebali and Farzinpour, 2006). Perlite is used in construction industry, insulation tiles, and concrete as aggregate. Expanded perlite is commonly used for herbicides, insecticides, and fertilizer as a carrier (Tekin, 2004). Moreover, it is commonly used in the processing of vegetable fat, juice, and beer in food industry. Also, it is used as a filter product in cleaning of dams and ponds in aquatic

Received: June 24, 2016

Accepted: October 26, 2016

*Corresponding author: fkarakasoguz@mehmetakif.edu.tr

http://dx.doi.org/10.1590/S1806-92902017000100004

How to cite: Karakas Oguz, F.; Gumus, H.; Oguz, M. N.; Bugdayci, K. E.; Dagli, H. and Ozturk, Y. 2017. Effects of different levels of expanded perlite on the performance and egg quality traits of laying hens. Revista Brasileira de Zootecnia 46(1):20-24.

Copyright () 2017 Sociedade Brasileira de Zootecnia. This is an Open Access article distributed under the terms of the Creative Commons Attribution License (http://creativecommons.org/licenses/by/4.0/), which permits unrestricted use, distribution, and reproduction in any medium, provided the original work is properly cited. environment to obtain a clear liquid, growing of seed, regulating of the soil in agriculture, and in so many other industrial applications (Alihosseini et al., 2010). Perlite has recently been used as an aflatoxin detoxicant and adsorbent in the removal of wastewater (Talebali and Farzinpour, 2006).

Feed constitutes approximately $70 \%$ of the cost in the poultry sector. After the usage of antibiotics were banned, researchers started to study on natural and synthetic feed additives to reduce feed costs and improve the quality of feed (Çelebi and Kaya, 2012). Some researchers have focused on perlite (Orhun, 1969; Talebali and Farzinpour, 2006), zeolite (Eleroğlu et al., 2011; Tatar et al., 2012), and sepiolite (Mizrak et al., 2014; Kavan et al., 2013). Perlite was found in Germany in 1925. Actually, the perlite industry began to develop in the United States in 1947 (Orhun, 1969). Turkey is one of the most important perlite producer countries; approximately 400,000 t perlite were produced in 2012 (Anonymus, 2013).

Zeolite, a hydrated aluminosilicate of alkali and alkaline soil cations, was discovered by mineralogist Fedrik Costeldt in 1756 (Çelebi and Kaya, 2012; Tatar et al., 2012). The zeolite structure is a specific arrangement, in which the unit cell contains 24 tetrahedra, $12 \mathrm{AlO}_{4}$, and $12 \mathrm{SiO}_{4}$. When fully hydrated, there are 27 water molecules and there is also one monovalent cation for each aluminum present (Kermanshahi et al., 2011). Dietary addition of zeolite has been shown to decrease the ammonia toxicity and aflatoxin toxicity in feedstuffs such as corn, wheat, and soybean (Miazzo et al., 2000). 
Sepiolite is an opaque and off-white, grey, or creamcolor natural mineral used in animal nutrition. It has high adsorption capacity (Mizrak et al., 2014). Sepiolite differs from the other clay minerals in terms of rheology importance. It is known as a relatively good ion exchanger due to its magnesium ion in the octahedral layer. (Mizrak et al., 2014). Magnesium ion releases more quickly, especially at low $\mathrm{pH}$ values. Transfer to a water solution of $\mathrm{Mg}$ at neutral $\mathrm{pH}$ (approximately 8.5 ) is $10^{-4} \mathrm{~mol} / \mathrm{L}$, increasing to $10^{-2}$ at $\mathrm{pH}=3$ (Mizrak et al., 2013). Maximum viscosity value of sepiolite pH is 8 (Mart et al., 2001). Mizrak et al. (2013) reported that shape index, eggshell weight and thickness, albumen height, and Haugh unit were not affected by adding sepiolite (1-2\%).

The objective of this study was to investigate the effects of different dietary levels of expanded perlite on performance and egg quality traits of laying hens.

\section{Material and Methods}

All experimental procedures used in this study were approved by the Animal Ethics Committee of the University of Mehmet Akif Ersoy (Burdur - Turkey/case no. 93773921). In total, forty Lohmann Brown laying hens with uniform body weight were obtained from commercial flock at 30 weeks of age. The laying hens were assigned to four equal groups replicated five times with two hens. They were housed in wire cages $(30 \mathrm{~cm} \times 44 \mathrm{~cm} \times 44 \mathrm{~cm})$ which were

Table 1 - Ingredients of basal diet

\begin{tabular}{ll}
\hline Ingredient & $\mathrm{g} / \mathrm{kg}$ \\
\hline Wheat & 140 \\
Corn & 334 \\
Sunflower meal & 207 \\
Soybean meal (48\% crude protein) & 134 \\
Sunflower oil & 60 \\
Dicalcium phosphate & 16 \\
Limestone & 100 \\
Salt & 3.5 \\
DL-methionine & 2.0 \\
L-lysine hydrochloride & 1.0 \\
Vitamin mineral premix ${ }^{1}$ & 2.5 \\
\hline${ }^{1}$ Vitamin and mineral premix provided per kilogram of diet: vitamin A, 12,000 000 IU; \\
vitamin E, 20,000 mg; manganese, 50,000 mg; iron, 50,000 mg; zinc, 50,000 mg; \\
copper, 10,000 mg; cobalt, 150 mg; selenium, 150 mg.
\end{tabular}

two-tiered and three-sided. Room temperature $\left(18 \pm 2{ }^{\circ} \mathrm{C}\right)$ was recorded daily and light program consisted of $16 \mathrm{~h}$ of light/day throughout the study. The study consisted of the non-supplemented perlite basal diet (control group). The different inclusion level of perlite $(1,2$, and $3 \%$ ) was added to basal diet weekly. All diets and water were provided ad libitum during the seven-week experimental period. The diets were formulated as NRC (1994) requirements (Table 1). Perlite was supplied from Genper Company.

Nutrient composition of concentrates was determined according to the AOAC (2003); crude fiber was determined by the methods of Crampton and Maynard (1938); the metabolizable energy levels (Table 2) of concentrated feeds were determined by the methods of Tittus and Fritz (1971).

The hens were weighed individually at the beginning and end of the study. For each cage, eggs were counted daily and weighed weekly. Feed intake and feed conversion ratio (FCR) were determined weekly. Feed conversion ratio was calculated by determining the amount of feed consumed per one kilogram of egg production and one kilogram of feed per dozen eggs.

Egg quality was determined in 10 eggs collected randomly from 09:30 to 12:30 $\mathrm{h}$ from each replicate on two consecutive days biweekly. The egg width $\left(\mathrm{E}_{\mathrm{w}}\right)$ and egg length $\left(\mathrm{E}_{\mathrm{L}}\right)$ were measured by digital calipers (Absolute digimatic caliper/series 500) to determine shape index $\left[\%=\left(\mathrm{E}_{\mathrm{w}} / \mathrm{E}_{\mathrm{L}}\right) \times 100\right]$.

The egg was broken onto a glass-topped table. The height of the albumen $\left(\mathrm{A}_{\mathrm{H}}\right)$ and the yolk $\left(\mathrm{Y}_{\mathrm{H}}\right)$ was measured with a tripod micrometer (Mitutoyo, No. 2050S-19, 0.01-20 mm; Kawasaki, Japan). To determine yolk index $\left[\mathrm{Y}_{\mathrm{I}}=\left(\mathrm{Y}_{\mathrm{H}} / \mathrm{Y}_{\mathrm{D}}\right)\right.$ $\times 100]$, albumen index $\left[\mathrm{A}_{\mathrm{I}}=\mathrm{A}_{\mathrm{H}} /\left[\left(\mathrm{A}_{\mathrm{L}}+\mathrm{A}_{\mathrm{W}}\right) / 2\right] \times 100\right]$, and Haugh unit $\left[\mathrm{H}_{U}=100 \log\right.$ (Albumen height $+7.57-1.7 \times$ Egg weight $\left.{ }^{0.37}\right)$ ] (Haugh, 1937), the length $\left(A_{L}\right)$ and width $\left(\mathrm{A}_{\mathrm{W}}\right)$ of the albumen and the diameter of the yolk $\left(\mathrm{Y}_{\mathrm{D}}\right)$ were measured using a digital caliper (Yalçın et al., 2014).

The cage of each group was cleaned one day before the end of trial. Fecal samples $(n=20)$ were collected from litter tray and weighed at the end of trial; then they were dried at $65{ }^{\circ} \mathrm{C}$ in a laboratory oven. Then, dry matter was calculated. To determine fecal $\mathrm{pH}, 25 \mathrm{~g}$ sample were mixed to $100 \mathrm{~mL}$ distilled water for $5 \mathrm{~min}$ with a blender. Fecal

Table 2 - Chemical composition of the diets (\%)

\begin{tabular}{|c|c|c|c|c|c|c|c|}
\hline Group & Dry matter & Ash & Organic matter & Crude protein & Ether extract & Crude fiber & $\begin{array}{c}\text { Metabolizable energy }{ }^{1} \\
(\mathrm{kcal} / \mathrm{kg})\end{array}$ \\
\hline Control & 90.36 & 10.38 & 79.98 & 16.90 & 8.08 & 3.27 & 2500 \\
\hline $1 \%$ perlite & 90.04 & 12.90 & 77.14 & 16.97 & 8.61 & 3.86 & 2415 \\
\hline $2 \%$ perlite & 90.42 & 15.16 & 75.26 & 16.82 & 9.07 & 3.30 & 2390 \\
\hline $3 \%$ perlite & 90.78 & 15.52 & 75.26 & 16.84 & 8.48 & 3.40 & 2370 \\
\hline
\end{tabular}

${ }^{1} \mathrm{MJ} / \mathrm{g}=133.06$ (crude protein) +232.91 (ether extract) -4.68 (crude fiber) +122.77 (nitrogen-free extract) (Tittus and Fritz, 1971). 
$\mathrm{pH}$ was measured using $\mathrm{pH}$ meter from this filtrate (Polan et al., 1998). This filtrate was centrifuged at $4200 \mathrm{rpm}$ for 10 min and then $\mathrm{NH}_{3}-\mathrm{N}$ was determined with distillation (Filya et al., 1997).

Statistical analyses were carried out using SPSS program (SPSS Inc., Chicago, IL, USA). Data were analyzed in one-way ANOVA and significant differences were calculated using Duncan's test (Dawson and Trapp, 2001). Level of significance was taken as $\mathrm{P}<0.05$.

\section{Results and Discussion}

Dietary treatments did not significantly affect final body weight, feed intake, and egg yield (Table 3 ). However, FCR was increased $(\mathrm{P}=0.02)$ and egg weight was decreased ( $\mathrm{P}=0.03$ ) significantly by addition of $2 \%$ perlite. While few studies have been carried out on the effects of perlite on performance of broiler chickens (Talebali and Farzinpour, 2006; Ghalehkandi et al., 2011; Tatar et al., 2012), no study has been designed with laying hens. Ghalehkandi et al. (2011) reported that weight gain was significantly affected by $2 \%$ perlite treatment rather than $4 \%$ perlite treatment and control group. Talebali and Farzinpour (2006) added 1,2 , and $3 \%$ perlite to broiler ration and reported that the $1 \%$ perlite group had significant differences in terms of weight (C: $1397 ; 1 \%$ perlite: $1624 \mathrm{~g}$ ) and FCR (C: 0.38 ; $1 \%$ perlite: 0.44$)$. Glodek (1980) added perlite to pig ration and found that daily weight gain was higher than in the other groups. According to the author, perlite has a carrier characteristic as an aluminum silicate. Several different silicates (zeolite, aluminosilicates, sepiolite-phyllosilicate) were used in laying hens. Yalçın et al. (1987) reported that adding $4 \%$ zeolite to ration of laying hens improved weight gain and FCR. Kavan et al. (2013) found that addition of clinoptilolite (zeolite) to diet caused significant differences in terms of body weight gain and FCR. While some researchers found concordance with the present results (Karamanlis et al., 2008; Abaş et al., 2011), some did not agree with them (Fisinin et al., 1985; Öztürk et al., 1998; Wu et al., 2013). Feed conversion ratio and egg mass had an improvement by adding 1.5\% sepiolite (Mizrak et al., 2014).
Because the viscosity in the jejenum was reduced by the sepiolite supplementation, the positive effect of sepiolite on the feed conversion was improved (Ouhida et al., 2000). With addition of zeolite to ration, passage rate of feeds through digestive tract was decreased and nutrients were more exposed to digestive tract enzymes (Khambualia et al., 2009). Ghalehkandi et al. (2014) found that different levels of perlite significantly increased average villi height in broilers. Also, the author pointed out that there would be a good relationship between section of intestine and weight gain. Khambualai et al. (2009) reported that addition of $0.5 \mathrm{~g} / \mathrm{kg}$ zeolite to duck ration increased duodenal villus height and area with corresponding body weight gain.

According to the results of this study, different levels of perlite had no effect on shape index, yolk index, and albumen index (Tables 4, 5, 6 and 7). However, in the 2\% perlite group, Haugh unit was decreased significantly and albumen index was numerically lower than in the other groups. Nassiri et al. (2008) reported that addition of zeolite to ration of laying hens reduced Haugh unit. As they state, zeolite reduced phosphorus availability for production of phosphoproteins contained in egg albumen. Olver (2007) did not observe any significant differences in Haugh unit by adding zeolite to ration of hens. Fendri et al. (2012) found a positive effect on albumen weight and egg weight by adding $1 \%$ zeolite. Mizrak et al. (2013) reported that shape index, eggshell weight and thickness, albumen height, and Haugh unit were not affected by adding sepiolite (1-2\%). Mizrak et al. (2014) observed that using sepiolite (1.5-3\%) did not affect the internal and external qualities among groups. Kermanshahi et al. (2011) indicated that addition of zeolite did not significantly affect egg production and egg weight among treatments, but yolk color index was significantly affected.

Dietary treatments did not significantly affect fecal $\mathrm{pH}$, dry matter, and $\mathrm{NH}_{3}-\mathrm{N}$. The $\mathrm{pH}$ of the feces of laying hens in 3\% perlite was higher than that of the other groups (Table 8). The results of the present study are in agreement with previous findings reported by Mizrak et al. (2014). However, Mizrak et al. (2013) found that fecal pH and dry matter were increased by adding sepiolite $(2 \%)$.

Table 3 - The effects of different levels of perlite on performance of laying hens

\begin{tabular}{|c|c|c|c|c|c|}
\hline & Control & $1 \%$ perlite & $2 \%$ perlite & $3 \%$ perlite & P-value \\
\hline Initial body weight (g) & $1959.50 \pm 64.87$ & $1993.50 \pm 52.54$ & $1968.00 \pm 42.49$ & $1933.00 \pm 56.09$ & 0.89 \\
\hline Final body weight (g) & $1948.88 \pm 71.53$ & $1918.50 \pm 58.09$ & $1956.50 \pm 36.06$ & $1871.10 \pm 53.96$ & 0.69 \\
\hline Feed intake (kg/day) & $0.107 \pm 0.02$ & $0.114 \pm 0.05$ & $0.113 \pm 0.01$ & $0.109 \pm 0.02$ & 0.65 \\
\hline Egg yield (\%) & $98.01 \pm 0.74$ & $97.85 \pm 1.49$ & $96.42 \pm 4.18$ & $98.75 \pm 1.01$ & 0.47 \\
\hline Feed conversion ratio ( $\mathrm{kg}$ feed/dozen eggs) & $1.49 \pm 0.81$ & $1.40 \pm 0.60$ & $1.41 \pm 0.26$ & $1.33 \pm 0.20$ & 0.15 \\
\hline Feed conversion ratio (kg feed/kg egg) & $1.79 \pm 0.01 b$ & $1.80 \pm 0.03 b$ & $1.90 \pm 0.02 \mathrm{a}$ & $1.79 \pm 0.02 b$ & $0.02 *$ \\
\hline Egg weight (g) & $64.94 \pm 1.36 \mathrm{a}$ & $63.46 \pm 0.51 \mathrm{ab}$ & $59.87 \pm 0.77 \mathrm{c}$ & $61.07 \pm 0.48 \mathrm{bc}$ & $0.03 *$ \\
\hline
\end{tabular}

* Means within rows with different letters are significantly different $(\mathrm{P}<0.05)$. 
Table 4 - Shape index $(\%)$

\begin{tabular}{lccccc}
\hline Week & Control & $1 \%$ perlite & $2 \%$ perlite & $3 \%$ perlite & P-value \\
\hline 2 & $78.67 \pm 0.97$ & $79.13 \pm 0.45$ & $78.88 \pm 0.52$ & $78.08 \pm 0.53$ & 0.68 \\
4 & $77.27 \pm 0.80$ & $79.23 \pm 0.88$ & $78.61 \pm 0.75$ & $77.67 \pm 0.50$ & 0.26 \\
6 & $78.24 \pm 0.92$ & $79.09 \pm 0.86$ & $78.33 \pm 0.73$ & $77.87 \pm 0.57$ & 0.73 \\
8 & $77.20 \pm 0.78$ & $77.69 \pm 0.74$ & $77.36 \pm 0.56$ & $79.27 \pm 2.12$ & 0.63 \\
$0-8$ & $77.85 \pm 0.36$ & $78.81 \pm 0.40$ & $78.30 \pm 0.45$ & $78.24 \pm 0.70$ & 0.62 \\
\hline
\end{tabular}

Table 5 -Yolk index (\%)

\begin{tabular}{lccccc}
\hline Week & Control & $1 \%$ perlite & $2 \%$ perlite & $3 \%$ perlite & P-value \\
\hline 2 & $44.22 \pm 1.18$ & $44.49 \pm 0.56$ & $43.19 \pm 0.78$ & $42,72 \pm 0.51$ & 0.33 \\
4 & $43.34 \pm 0.83$ & $43.69 \pm 0.71$ & $43.74 \pm 0.60$ & $43.53 \pm 0.82$ & 0.98 \\
6 & $43.62 \pm 0.68$ & $43.23 \pm 0.91$ & $42.76 \pm 0.71$ & $42.84 \pm 0.84$ & 0.86 \\
8 & $42.48 \pm 0.90$ & $43.01 \pm 0.63$ & $40.73 \pm 0.86$ & $42.10 \pm 0.68$ & 0.21 \\
$0-8$ & $43.42 \pm 0.60$ & $43.61 \pm 0.27$ & $42.60 \pm 0.47$ & $42.74 \pm 0.44$ & 0.32 \\
\hline
\end{tabular}

Table 6 - Albumen index (\%)

\begin{tabular}{lccccc}
\hline Week & Control & $1 \%$ perlite & $2 \%$ perlite & $3 \%$ perlite & P-value \\
\hline 2 & $9.07 \pm 0.60$ & $10.14 \pm 0.51$ & $8.23 \pm 0.36$ & $9.11 \pm 0.46$ & 0.06 \\
4 & $8.50 \pm 0.68$ & $10.10 \pm 0.56$ & $8.34 \pm 0.42$ & $8.95 \pm 0.59$ & 0.12 \\
6 & $8.76 \pm 0.94$ & $9.69 \pm 0.56$ & $7.48 \pm 0.18$ & $8.97 \pm 0.64$ & 0.10 \\
8 & $9.14 \pm 0.84$ & $9.62 \pm 0.70$ & $7.58 \pm 0.30$ & $8.22 \pm 0.64$ & 0.12 \\
$0-8$ & $8.87 \pm 0.74$ & $9.89 \pm 0.66$ & $7.91 \pm 0.32$ & $8.81 \pm 0.65$ & 0.09 \\
\hline
\end{tabular}

Table 7 - Haugh unit

\begin{tabular}{lccccc}
\hline Week & Control & $1 \%$ perlite & $2 \%$ perlite & $3 \%$ perlite & P-value \\
\hline 2 & $94.25 \pm 1.66$ & $97.70 \pm 1.41$ & $92.25 \pm 1.19$ & $95.32 \pm 1.34$ & 0.07 \\
4 & $92.79 \pm 2.32$ & $97.66 \pm 1.53$ & $92.51 \pm 1.46$ & $94.51 \pm 1.64$ & 0.14 \\
6 & $93.01 \pm 2.52$ & $95.12 \pm 1.56$ & $89.92 \pm 0.66$ & $93.85 \pm 2.22$ & 0.26 \\
8 & $94.64 \pm 2.29$ & $96.83 \pm 1.87$ & $90.58 \pm 0.99$ & $91.33 \pm 1.99$ & 0.07 \\
$0-8$ & $93.55 \pm 1.61 \mathrm{ab}$ & $96.83 \pm 0.87 \mathrm{~b}$ & $91.32 \pm 0.62 \mathrm{a}$ & $93.69 \pm 1.33 \mathrm{ab}$ & $0.02 *$ \\
\hline
\end{tabular}

* Means within row with different letters are significantly different $(\mathrm{P}<0.05)$.

Table 8 - Effects of different levels of perlite on some fecal parameters

\begin{tabular}{lccccc}
\hline & Control & $\begin{array}{c}1 \% \\
\text { perlite }\end{array}$ & $\begin{array}{c}2 \% \\
\text { perlite }\end{array}$ & $\begin{array}{c}3 \% \\
\text { perlite }\end{array}$ & P-value \\
\hline Fecal pH & 6.47 & 6.50 & 6.49 & 6.67 & 0.54 \\
Fecal dry matter & 33.23 & 32.70 & 31.03 & 31.74 & 0.84 \\
Fecal $\mathrm{NH}_{3}-\mathrm{N}(\mathrm{mg} / \mathrm{g}$ & 1.15 & 1.30 & 1.22 & 1.36 & 0.93 \\
dry matter of feces) & & & & & \\
\hline
\end{tabular}

\section{Conclusions}

Dietary perlite supplementation has no significant effects on shape, yolk, and albumen index and no negative effect on performance and egg quality traits, except at $2 \%$ level. Dietary expanded perlite can be added at $1 \%$ level in laying hen rations without changing the animal performance.

\section{References}

Abaş, İ.; Bilal, T. and Eseceli, H. 2011. The effect of organic acid, zeolite, or their combination on performance, some serum indices, and ileum $\mathrm{pH}$ values in broilers fed with diff erent phosphorus levels. Turkish Journal of Veterinary Animal 35:337-344.

Alihosseini, A.; Taghikhani, V.; Safekordi, A. A. and Bastani, D. 2010. Equilibrium sorption of crude oil by expanded perlite using different adsorption isotherms at $298.15 \mathrm{k}$. International Journal of Environmental Science and Technology 7:591-598.

Anonymus. 2013. Perlite. Available at: <http://minerals.usgs.gov/ minerals/pubs/commodity/perlite/mcs-2013-perli.pdf.>. Accessed on: June. 15, 2015.

AOAC - Association of Official Analytical Chemists. 2003. Official methods of analysis. 17th ed. 2nd rev., Gaithersburg, MD, USA.

Crampton, E. W. and Maynard, L. A. 1938. The relation of cellulose and lignin content to nutritive value of animal feeds. Journal of Nutrition 15:383-395.

Çelebi, S. and Kaya, A. 2012. Yumurta Tavuğu ve Broyler Yemlerinde Zeolit Kullanımı. Hayvansal üretim 53:40-48.

Dawson, B. and Trapp, R. G. 2001. Basic and clinical biostatistics. 3th ed. Lange Medical Books McGraw-Hill Medical Publishing Division, New York.

Eleroğlu, H.; Yalçın, H.; Yıldırım, A. and Aker, A. 2011. Etlik Piliç Yemine Doğal Zeolit İlavesinin Besi Performansı Üzerine Etkileri. Hayvansal üretim 52:24-32.

Fendri, I.; Khannous, L.; Mallek, Z.; Traore, I.; Gharsallah, N. and Gdoura, R. 2012. Influence of Zeolite on fatty acid composition and egg quality in Tunisian laying hens. Lipids in Health and Disease 11:71-77.

Filya, İ.; Karabulut, A. and Iş1k, Y. 1997. Bursa bölgesinde silo yemi üretimi ve kullanımı üzerine bir araştırma. p.24-31. In: Türkiye Birinci Silaj Kongresi. Uludağ University, Bursa.

Fisinin, V.; Agecv, V.; Sintserova, O.; Lenkova, T. and Kvashali, N. 1985. Zeolites in diets for poultry. Ptitsevodstvo 9:25-26. Poultry Abstr. (86)12.

Ghalehkandi, G.; Valilu, M.; Ebrahimnazhad, Y.; Nobar, R.; Karamouz, H. and Nazeri, M. 2011. Effect of different levels of perlite on performance of broiler chicks. Advances in Environmental Biology 5:776-779.

Ghalehkandi, G.; Hassanpour, S.; Ebrahimnezhad, Y.; Beheshti, R. and Maheri, N. 2014. Intestinal morphograhy of broilers fed diets supplemented with perlite. Journal of the Hellenic Veterinary Medical Society 65:99-108.

Glodek, P. 1980. Perlite in hogs fattened feeds. University of Gottingen, Germany.

Haugh, R. R. 1937. The Haugh Unit for measuring egg quality. U. S. Egg Poultry Magazine 43:522-555.

Karamanlis, X.; Fortomaris, P.; Arsenos, G.; Dosis, I.; Papaioannou, D.; Batzios, C. and Kamarianos, A. 2008. The effect of a natural zeolite (clinoptilolite) on the performance of broiler chickens and the quality of their litter. Asian-Australasian Journal of Animal Sciences 21:1642-1650.

Kavan, P. B.; Shargh, S. M.; Hassani, S. and Mostafalo, Y. 2013. Effects of physical size of clinoptilolite on growth performance, serum biochemical parameters and litter quality of broiler chickens in the growing phase. Poultry Science 1:93-104.

Kermanshahi, H.; Haji Agha Jani, E.; Hashemipour, H. and Pilevar, M. 2011. Efficacy of natural zeolite and pigments on yolk color and performance of laying hens. African Journal of Biotechnology 10:3237-3242

Khambualai, O.; Ruttanavut, J.; Kitabatake, M.; Goto, H.; Erikawa, T. and Yamauchi, K. 2009. Effects of dietary natural zeolite including 
plant extract on growth performance and intestinal histology in Aigamo ducks. British Poultry Science 50:123-130.

Mart, U.; Yüzer, H.; Sabah, E. and Çelik, M. S. 2001. Sepiyolitin su bazlı sistemlerde vizkozite davranışı. p.121-128. In: 10. Ulusal Kil sempozyumu, Konya.

Mırak, C.; Yenice, E. and Ertekin, B. 2013. Düsük düzeyde kalsiyum içeren damızlık yumurta tavugu yemlerine ilave edilen sepiyolitin performans, yumurta kalite kriterleriyle, bazı kan ve sindirim sistemi özellikleri üzerine etkisi. Lalahan Hayvancılık Araştırma Enstitüsü Dergisi 53:75-89.

Mızrak, C.; Yenice, E.; Kahraman, Z.; Tunca, M.; Yıldırım, U. and Necmettin C. 2014. Effects of dietary sepiolite and mannanoligosaccharide supplementation on the performance, egg quality, blood and digestion characteristics of laying hens receiving aflatoxin in their feed. Ankara Üniversitesi Veteriner Fakültesi Dergisi 61:65-71.

Miazzo, R.; Rosa, C. A. R.; Carvaho, E. C. Q; Magnoli, C.; Chiacchiera, S. M.; Palacio, G.; Saenz, M.; Kikot, A.; Basaldella, E. and Dalcero, A. 2000. Efficacy of synthetic zeolite to reduce the toxicity of aflatoxin inbroiler chicks. Poultry Science 79:1-6.

Nassiri, H. M.; Jahanian, R.; Jahanian, H. N. and Madaeni, M. M. 2008. Influence of dietary zeolite supplementation on the performance and egg quality of liying hrns fed varying levels of calcium and nonphytate phosphorus. Journal of Biological Sciences 8:328-334.

NRC - National Research Council. 1994. Nutrient requirements of poultry. NRC, Washington, DC, USA.

Olver, M. D. 1997. Effect of feeding clinoptilolite (zeolite) on the performance of three strains of laying hens. British Poultry Science 38:220-222.

Orhun, O. 1969. Perlite. Available at: <http://www.maden.org.tr/ resimler/ekler/498.pdf>. Accessed on: June 15, 2015.

Ouhida, I.; Perez, J. F.; Piedraita, J. and Gasa, J. 2000. The effects of sepiolite in broiler chicken diets of high, medium and low viscosity.
Productive performance and nutritive value. Animal Feed Science and Technology 85:183-194.

Öztürk, E.; Erener, G. and Sarıca, M. 1998. Influence of natural zeolite on performance of laying hens and egg quality. Turkish Journal of Agriculture and Forestry 22:623-628.

Polan, C. E.; Stieve, D. E. and Garrett, J. L. 1998. Protein preservation and ruminal degradation of ensiled forage treated with heat, formic acid, ammonia, or microbial inoculant. Journal of Dairy Science 81:765-776.

Talebali, H. and Farzinpour, A. 2006. Effect of different levels of perlite on performance of broiler chicks. International Journal of Poultry Science 5:432-435.

Tatar, A.; Boldaji, F.; Dastar, B.; Hassani, S. and Yalçin, S. 2012. Effects of dietary supplementation with perlite and zeolite on performance, litter quality and carcass characteristics of broilers from 7-42 days of age. International Journal of Basic and Applied Sciences 3:1148-1154.

Tekin, G. 2004. Perlit ve spiyolit'in amonyumheptamolibdat ile modifikasyonu ve elektrokinetik özellikleri. Balıkesir Üniversitesi Fen Bilimleri Enstitüsü dergisi 6(2).

Tittus, H. W. and Fritz, J. C. 1971. Percentage multipliers for computing metabolizable energy values, for chickens, of some feedstuffs used in the feeding of poultry. In: The scientific feeding of chickens. 5th ed. Interstate, Danville, IL.

Wu, Q. J.; Zhou, Y. M.; Wu, Y. N. and Wang, T. 2013. Intestinal Development and Function of Broiler Chickens on Diets Supplemented with Clinoptilolite. Asian-Australasian Journal of Animal Sciences 26:987-994.

Yalçın, S.; Ergün, A.; Çolpan, İ. and Küçükersan, K. 1987. Zeolitin yumurta tavukları üzerindeki etkileri. Lalahan Hayvancılık Araştırma Enstitüsü Dergisi 27:28-49.

Yalçın, S.; Yalçın, S.; Onbaşılar, İ.; Eser, H. and Şahin, A. 2014. Effects of dietary yeast cell wall on performance, egg quality and humoral immune response in laying hens. Ankara Üniversitesi Veteriner Fakültesi Dergisi 61:289-294. 